DOI : 10.14746/pp.2014.19.2.14

\title{
Aleksandra ZIĘBA
}

Warszawa

\section{Female terrorism w Stanach Zjednoczonych}

\begin{abstract}
Streszczenie: Zasadniczym tematem artykułu jest problem terroryzmu wewnętrznego z udzialem kobiet (female terrorism) w Stanach Zjednoczonych. Dodatkowo poruszono kwestie związane z próbą znalezienia odpowiedzi na pytania, czy system przeciwdziałania terroryzmowi powinien uwzględniać specyfikę plci członków organizacji terrorystycznych oraz czy wzrastające zagrożenie terroryzmem kobiecym może być jednym z katalizatorów zmian instytucjonalno-prawnych. Celem scharakteryzowania zjawiska ukazano również rozwój terroryzmu kobiecego w innych regionach świata.
\end{abstract}

Słowa kluczowe: terroryzm, terroryzm kobiet, zwalczanie terroryzmu, USA, WASP, dżihad

\section{Terroryzm z udzialem kobiet}

C elem artykułu jest pogłębienie analizy zjawiska przemocy politycznej postrzeganej przez pryzmat zaangażowania kobiet w Stanach Zjednoczonych. Płeć może być istotnym elementem również w badaniach nad terroryzmem. Zrozumienie motywów partycypacji kobiet $\mathrm{w}$ tej formie radykalnej przemocy, mogłoby przybliżyć zrozumienie samego zjawiska, jakim jest proces stawania się terrorystą. Jednak spojrzenie przez pryzmat płci niekoniecznie wygeneruje rezultat, jakim będzie realizowanie zadań przez instytucje zajmujące się zwalczaniem terroryzmu z uwzględnieniem jej specyfiki. Kwestia płci może mieć tu marginalne znaczenie wobec zagrożenia bezpieczeństwa i porządku publicznego. Większe znaczenie będzie miało modus operandi stosowane wyłącznie przez kobiety (np.: większe możliwości kamuflażu, przenikania do niektórych środowisk, niepostrzeżonego przekraczania punktów granicznych i kontrolnych). Karla J. Cunningham zauważa braki w systemie zwalczania terroryzmu, w szczególności reagowania na terroryzm kobiet na poziomie:

1) wykorzystania kobiet przebywających w więzieniach w celach informacyjnych i operacyjnych;

2) struktury organizacyjnej;

3) technologii:

4) oszustwa i zdrady (wykorzystanie kobiet dla rozpracowania organizacji, również od środka);

5) zalet taktycznych;

6) kultury i ideologii (Cunningham, 2012).

Prawdopodobnie ten ostatni element ma decydujące znaczenie w przeprowadzaniu spektakularnych zamachów, w tym zamachów samobójczych. Sukcesy kobiet terrorystek stanowią dowód, że terroryzm z udziałem kobiet (female terrorism) powinien być analizowany przez badaczy, analityków i ekspertów, w celu podniesienia efektywności operacyjnej instytucji zajmujących się jego zwalczaniem. Analiza zaangażowania kobiet 
w przemoc polityczną, w życie polityczne poszerza naszą wiedzę o rodzaju ludzkim i aktywności politycznej w ogóle, nie służy przeciwstawieniu mężczyzn kobietom (O'Gorman, Jabri, 1999, s. 7-8; Wesley 2006).

Partycypacja kobiet w działalności terrorystycznej ma długą tradycję. Odgrywały one istotną rolę w pierwszej fali terroryzmu anarchistycznego (Rapoport, 2004) ${ }^{1}$. Stanowiły 1/4 członków organizacji Narodnaja Wola, z wyróżniającymi się Wierą Nikołajewną Figner i Zofią Lwowną Perowską, które przygotowywały zamach na cara Aleksandra II w marcu 1881 r. (Bazylow, 1960; Smith, Carroll, 2000, s. 233-242). Udział kobiet w fali anarchistycznej wpisywał się w nurt emancypacyjny, jaki ta fala niosła ze sobą. Aktywność kobiet zanikła w fali drugiej, by odrodzić się w latach 60 . XX wieku w ruchach świeckich, przede wszystkim lewicowych, ale także narodowowyzwoleniczych. Kobiety pełnily funkcje wspólliderów, np. Ulrike Meinhhof we Frakcji Czerwonej Armii (Rote Armee Fraktion - RAF), Fusako Shingenobu w Japońskiej Czerwonej Armii (Nihon Sekigu - JRA) czy Adriana Faranda we włoskich Czerwonych Brygadach (Brigate Rosse - BR). Ugrupowania lewicowe były bardziej otwarte na partycypację kobiet, bo ich ideologia miała na celu zerwanie z przeszłością, w przypadku ruchów prawicowych powrót do przeszłości ma priorytetowe znaczenie. Nie znaczy to jednak, że kobiety żyjące w społecznościach bardziej konserwatywnych nie biorą udziału w walce politycznej. Świadczy o tym chociażby zaangażowanie kobiet w działalność Ludowego Frontu Wyzwolenia Palestyny (Popular Front for the Liberation of Palestine - PFLP), z sztandarowa postacią Leili Khaled (Irving, 2012; Khaled, 1973; MacDonald, 1992). Współcześnie również kobiety-terrorystki statystycznie bardziej związane są z ruchami lewicowymi i mającymi charakter świecki, rzadziej angażują się w działalność organizacji religijnych lub prawicowych (Nacos, 2005, s. 436). Niemniej kobiety stanowią ponad $25 \%$ prawicowych organizacji w USA i aż 50\% nowych rekrutów w takich ruchach rasistowskich, neonazistowskich i supremacjonistycznych jak, np. Narody Aryjskie (Aryan of Nations) oraz Ruch Tożsamości Chrześcijańskiej (Creativity Movement), (Blee, 2005). Od drugiej połowy lat 80 . XX wieku ponad 30\% zamachów na świecie przygotowywanych jest właśnie przez kobiety (Bloom, 2005).

Sam terroryzm, tak jak i rewolucja, rewolta, konflikt zbrojny nie ma płci. Na pewno pozycja kobiety w określonym kręgu kulturowym, w której funkcjonuje dana organizacja terrorystyczna, odgrywa niebagatelne znaczenie. Udział kobiet, szczególnie w organizacjach dotychczas dla nich zamkniętych, w pewien sposób sprzyja poprawie wizerunku danej organizacji i umacnia jej pozycję w społecznościach, w których ona funkcjonuje. Wiąże się z tym kwestia moralnego potępienia zbrodni. Medialny wizerunek kobiety - terrorystki jest zdecydowanie rzadszy niż postać zamaskowanego mężczyzny z AK-47. Gdy kobieta jest uczestnikiem ataku terrorystycznego oburzenie społeczności międzynarodowej, często przeplata się z poszukiwaniem usprawiedliwienia w jej doświadczeniach życiowych, przeżytej traumie lub krzywdzie. Bardzo trudno uwierzyć bowiem, że kobie-

${ }^{1}$ David A. Rapoport wyodrębnił w historii terroryzmu cztery charakterystyczne fale. Fala jest w jego ujęciu cyklem działalności mającym charakter międzynarodowy, która obejmuje zarówno okres rozwoju, jak i stagnacji. Za I falę uznal anarchistyczną (1879-1914), II falę antykolonialną (1918-koniec 1. 60. XX w.), III falę neolewicową (druga połowa 1. 60. do końca lat 80 . XX w.) oraz IV falę religijną (od 1979 roku). Nazwy poszczególnych fal pochodzą od idei przewodniej wyróżniającej się w tym okresie. 
ta jako symbol życia, życie to dla sprawy odbiera (Zięba, 2013). Wskazuje się na czynniki psychologiczne: wielorakie krzywdy, których doznała w dzieciństwie, brak tożsamości, byciu poniżaną, czynniki polityczne: okupacja, dyskryminacja lub ekonomiczne: ubóstwo, brak pracy. Jednak poszukiwanie specyficznych cech osobowości terrorystycznej, w tym zaburzeń psychicznych nie powiodło się. Z punktu widzenia organizacji terrorystycznej osoby z zaburzeniami psychicznymi nie są atrakcyjne również jako wykonawcy większości zadań. Trudno nad nimi zapanować. To oznacza, że terrorystą może stać się osoba racjonalnie myśląca (Horgan, 2008, s. 43-97).

\section{Motywy zaangażowania kobiet $\mathbf{w}$ terroryzm}

Najczęściej akcentowanymi motywami działalności kobiet w organizacjach są czynniki osobiste, jak np.: zaangażowanie rodziny w działalność terrorystyczną; doświadczenie śmierci członka rodziny zadanej przez „wroga” i towarzysząca temu chęć zemsty; bezpłodność lub też pozostawanie niezamężną co stygmatyzuje daną kobietę w patriarchalnych społeczeństwach. Często działalność terrorystyczna, a przede wszystkim samobójcza będzie miała na celu podniesienie prestiżu danej kobiety i całej jej rodziny w społeczności lub - podobnie jak w przypadku samobójstw fatalistycznych w sektach religijnych - znaczenie może mieć konformizm grupowy (El Saaraj, 2002; Victor, 2003; Berko, 2010; Brym, Araj, 2012). Mimo iż są to obiektywne przesłanki, trudno stwierdzić, który czynnik i w jakim stopniu przyczynił się do zaangażowania kobiet w działalność terrorystyczną. Innymi przesłankami zaangażowania kobiet w terroryzm mogą być: silna indoktrynacja ze strony członków organizacji terrorystycznych, granicząca często z manipulacją emocjonalną i zastraszaniem, aktywność w nich członków rodzin zwerbowanych kobiet oraz wzorowanie się na swoich poprzedniczkach. Taki wizerunek terrorystki budzi współczucie, nie kwalifikuje jej działalności w kategoriach przestępstw przeciwko życiu. Mierzalne są tylko skutki przemocy na poziomie autoagresji czy agresji skierowanej na zewnątrz. Tłumaczenie aktów terroru dokonywanych przez kobiety jako aktów rozpaczy, relatywizuje zbrodnię, przyozdabiając ją w cechy budzące współczucie, niekiedy sympatię (eufemistyczny język: „,zarne wdowy”, „,białe wdowy”). Czynnikami najczęściej akcentowanymi są: wspomniany już akt zemsty po utracie bliskiej osoby, odkupienie (np. zmycie hańby z siebie lub z członków rodziny), wzbudzenie podziwu wśród społeczności (kult męczeństwa, czy też nadanie sensu istnienia poprzez przynależność do organizacji) oraz bliskie relacje osobiste z członkami organizacji (związki emocjonalne). Motywy te mogą mieć znaczenie - z perspektywy organizacji werbującej daną kobietę - podczas procesu kadrowego i etapowego (weryfikacja kandydata, przygotowanie i ocena stopnia gotowości) o szczególnym przeznaczeniu, np. do zamachów samobójczych (Bloom, 2011).

Warto zwrócić uwagę, że organizacje wykorzystujące zamachy samobójcze kobiet wywodzą się częściej z kultur kolektywistycznych (Palestyna, Liban, Turcja, Sri Lanka). W nich rola społeczności, hierarchii, pozycji w grupie oraz potrzeba ochrony są olbrzymie. Tam także liczą się wartości związane z klanem, plemieniem i rodziną. Tożsamość jednostki w tych kulturach jest ściśle powiązana z podziałem świata na swoich (społeczność tworzącą dany system społeczny) oraz społeczność spoza systemu. W ramach takiego rozróżnienia może zaistnieć przyzwolenie na stosowanie radykalnej przemocy politycz- 
nej wobec obcych. Stanowi to swoisty dualny system moralny: wobec swoich i nie-swoich (Peterka-Benton, Benton, 2014). Trudno stwierdzić, że społeczeństwo amerykańskie jest kolektywistyczne. Nie jest też w pełni indywidualistyczne, choć idee indywidualizmu są propagowane i pożądane, szczególnie przez gospodarkę wolnorynkową. Michael Novak uznaje zarówno dziedzictwo amerykańskie, jak i wartość płynące z tradycji rodziny przybyłej z innego kraju, za podstawę natury społecznej. Przejawiać się będzie ona, $\mathrm{z}$ jednej strony w wyrozumiałości dla indywidualizmu, $\mathrm{z}$ drugiej zaś w potrzebie stowarzyszania i poczucia wspólnoty (Novak, 1988, s. 33-34). I właśnie w tych wspólnotach zaobserwować można zaangażowanie kobiet $\mathrm{w}$ przemoc polityczną, szczególnie $\mathrm{w}$ akcje antyaborcyjne i rasistowskie. William Lee Eubank i Leonard Weinberg uważaja, że demokracja sama w sobie, nie promuje terroryzmu, ale jest bardziej podatna (wrażliwa) na ataki terrorystyczne i stwarza warunki do radykalizacji grup osób, które przez ogólnodostępne kanały życia społecznego i politycznego mogą przekształcić się w organizację terrorystyczną (Eubank, Weinberg, 1994; Schmidt, 1992). W pewien sposób thumaczy to skalę terroryzmu wewnętrznego w Stanach Zjednoczonych, która jest skrajną formą manifestu politycznego. Jest degradacją, która następuje po wyczerpaniu dostępnych metod i form artykulacji potrzeb politycznych przez dany ruch społeczny/polityczny. Warto zaznaczyć, że metodami typowymi, charakteryzującymi terroryzm wewnętrzny w Stanach Zjednoczonych, nie są - jak dotąd - zamachy samobójcze.

Literatura, filmy, media wykreowały wizerunek wojny, konfliktu zbrojnego jako „walki”, tylko walki, w której role przypisywane są głównie żołnierzom-mężczyznom. Zapomina się przy tym, że oprócz zbrojnych akcji na danym terenie mieszkają również ludzie, którzy muszą jeść, spać, pracować i troszczyć się o bliskich. Jak w tym kontekście sytuuje się kobieta wobec mężczyzny, który od wieków uosabiany jest z walecznym wojownikiem? Czy jako ofiara, czy jako bojowniczka? (Nordstrom, 2008, s. 75). W potocznym rozumieniu uznaje się za „nienormalne” przywdzianie szat bojowników przez kobiety. Ich zachowania i postawy postrzega się jako maskulinizację w celu przetrwania. W ten sposób próbują pokazać, że są równie waleczne i zdolne do poświęceń jak mężczyźni. Ale i aspekt rywalizacji może odgrywać tu dużą rolę. Jednak takie podejście nie wyjaśnia, dlaczego w tak wielu różnorodnych nurtach i formach terroryzmu, w niejednorodnych systemach politycznych, kulturowych i religijnych kobiety są obecne nie tylko w organizacjach partyzanckich, ale też i w organizacjach terrorystycznych. I nie chodzi tu o procentowy udział (skale), ale sam fakt ich obecności ${ }^{2}$. Na najbardziej podstawowym poziomie, bycie częścią sił rebelianckich w regionach takich jak np. Ameryka Łacińska może zapewniać potrzebę wyżywienia i schronienia. Takie ugrupowania często dają ko-

\footnotetext{
${ }^{2}$ Grupy terrorystyczne, w których odnotowano militarną aktywność kobiet to m.in.: Brygady Męczenników Al-Aqsa, Al-Qa'ida i jej filie, ugrupowania stowarzyszone z Emiratem Kaukaskim, Kraj Basków i Wolność (ETA), Islamska Grupa Zbrojna (GIA), Hamas, Hezbollah, Grupa Islamska (JI), Tamilskie Tygrysy Wyzwolenia Ilamu (ETA), Partia Pracujących Kurdystanu (PKK), Ludowy Front Wyzwolenia Palestyny (LTTE), Prima Linea, Prowizoryczna Irlandzka Armia Republikańska (PIRA). Rewolucyjne Sily Zbrojne Kolumbii (FARC), Sandinowski Front Wyzwolenia Narodowego (FSLN). Zapatystowska Armia Wyzwolenia Narodowego (EZLN), Japońska Armia Czerwona (JAC), Czerwone Brygady (BR), Frakcja Czerwonej Armii (RAF), nawet istniała organizacja w RFN składająca się tylko z kobiet Rote Zora (1977-1995).
} 
bietom szansę na zdobycie pewnych umiejętności, które mogą być wykorzystane w życiu cywilnym. Na działalność terrorystyczną oprócz akcji zbrojnych składać się może cały szereg szkoleń nie tylko militarnych, lecz także politycznych, ekonomicznych oraz językowych. Kobiety uczą się pewności, której by nie mogły zdobyć w cywilnym życiu. W społeczeństwach, gdzie tradycja odgrywa ważną rolę, tymczasowy status bojownika może podnieść prestiż i niwelować mechanizmy charakteryzujące status kobiety. Niemniej, gdy przyjrzymy się patriarchalnej strukturze Świetlistego Szlaku (Sendero Luminoso) z Abimaelem Guzmanem na czele, trudno o potwierdzenie, że 40\% członkiń angażowała się w działalność tej organizacji, poszukując emancypacji (Ness, 2008, s. 17-18). Te same wątpliwości dotyczą Partii Pracujących Kurdystanu (Partiya Karkerên Kurdistan - PKK) z charyzmatycznym, autorytarnym liderem Abdullahem Öçalanem oraz Tamilskich Tygrysów Wyzwolenia Ilamu (Liberation Tigers of Tamil Eelam - LTTE) pod przywództwem Velupillaiego Prabhakarana (zm. 18.05.2009).

Karen Jacques i Paul Taylor z Uniwersytetu w Lancaster przeanalizowali życiorysy 222 kobiet i 269 mężczyzn zaangażowanych w różne ruchy terrorystyczne. Celem badania była identyfikacja podobieństw i różnic ze względu na kryteria: wieku, w którym nastapiło zaangażowanie się w terroryzm, poziomu wykształcenia, zatrudnienia, stanu cywilnego, statusu imigracyjnego, konwersji religijnej, związków z inną działalnością przestępczą oraz aktywizmem politycznym/społecznym. Analizie poddano życiorysy kobiet i mężczyzn związanych m.in. z Al-Qa'idă, Krajem Basków i Wolnością (Euskadi Ta Askatasuna - ETA), Irlandzką Armią Republikańską (Irish Republican Army - IRA), falą neolewicową w Europie (RAF, BR, Prima Linea), sektą Najwyższa Prawda (Aum Shinrikyo), Rewolucyjnymi Siłami Zbrojnymi w Kolumbii (Fuerzas Armadas Revolucionarias de Colombia - FARC), LTTE, PFLP, Al-Fatahem, Islamskim Ruchem Oporu (Harakat al-Muqāwamah al-Islāmīja - Hamas) oraz działającymi na terenie USA: Powstrzymać Okrucieństwo wobec Zwierząt w Huntington (Stop Hundignton Animal Cruelty - US-SHAC), Frontem Wyzwolenia Zwierząt (Animal Liberation Front - ALF), Frontem Wyzwolenia Ziemi (Earth Liberation Front - ELF) i Po Pierwsze Ziemia! (Earth First! - EF). Naukowcy odkryli, że w przeciwieństwie do niektórych stereotypowych wyjaśnień, kobiety terrorystki nie są niewykształconymi outsiderkami z zaburzeniami społecznymi. Poziom edukacji (co najmniej na poziomie szkoły średniej) i aktywności zawodowej (50\%) były wysokie. Większość z nich bardzo młodo zaangażowała się w działalność terrorystyczną (poniżej 35 roku życia), były autochtonami (native) i zazwyczaj nie miały wcześniejszych doświadczeń z przestępczością. Ciekawe jest, że prawie $1 / 3 \mathrm{z}$ badanych miała kontakty z terroryzmem poprzez swoją rodzine, czy krag znajomych (Jacques, Taylor, 2013). Aktywizm polityczny pozostałych członków rodziny mógł wpłynąć na zaangażowanie się kobiet $w$ terroryzm, jednak w regionach objętych okupacją lub konfliktem (Palestyna, Irlandia Północna, Czeczenia, Irak) nie będzie on czymś zaskakującym.

\section{Terroryzm wewnętrzny w USA}

Dział XVIII „Przestępstwa i postępowanie karne” Kodeksu Stanów Zjednoczonych (United States Code, U.S.C.) w rozdziale I Przestępstwa, w podrozdziale 113B poświęconym terroryzmowi, definiuje przestępstwo terroryzmu międzynarodowego i wew- 
nętrznego ( $\$ 2331$ ) oraz penalizuje m.in. użycie broni masowego rażenia ( $\$ 2332 \mathrm{a}$ ), przeprowadzanie zamachów bombowych w miejscach użyteczności publicznej ( $\$ 2332 \mathrm{f})$, ukrywanie terrorystów oraz osób podejrzanych o terroryzm $(\S 2339)$ i finansowanie terroryzmu ( $\S 2339 \mathrm{a}$, b). Za terroryzm wewnętrzny uznano działalność, która dotyczy działań niebezpiecznych dla życia podlegających jurysdykcji terytorialnej USA, w celu (przestępstwo kierunkowe o szczególnym zabarwieniu): (i) zastraszenia lub wymuszenia na ludności cywilnej; (ii) wpływu na politykę rządu przez zastraszenie lub przymus; lub (iii) wpływu na zachowanie rządu poprzez masowe rażenie, zabójstwa czy porwania (United States Code 2013). Również USA PATRIOT Act z 26 października 2001 roku w sekcji 802 przywołuje tę definicję terroryzmu wewnętrznego (USA PATRIOT Act 2001). Federalne Biuro Śledcze (Federal Biuro of Investigation - FBI), powołując się na definicje kodeksu USA, definiuje terroryzm jako „bezprawne użycie siły lub przemocy wobec osób lub mienia, w celu zastraszenia lub wywarcia przymusu na rząd, ludność cywilną albo część wyżej wymienionych, co zmierza do promocji celów politycznych lub społecznych" (FBI 2014). Wyróżnikiem terroryzmu wewnętrznego jest działanie na terytorium jednego państwa, nie znaczy to, że organizacje nie utrzymują kontaktów na zewnątrz. Organizacje o podobnym zapleczu ideowym działają też w innych państwach, częstym wzorcem sq̨ ugrupowania działające w Europie (ruch wyzwolenia zwierząt, ziemi, nazizm, marksizm).

Fenomenem w Stanach Zjednoczonych są organizacje zaliczane przez Federalne Biuro Śledcze do kategorii terroryzmu wewnętrznego (domestic terrorsim/homegrown terrorism). Jednak ani FBI, ani Departament Sprawiedliwości (Department of Justice) czy Departament Bezpieczeństwa Wewnętrznego (Department of Homeland Security) nie publikują list takich organizacji. Jedynie upubliczniane są listy organizacji zaliczanych do terroryzmu międzynarodowego Foreign Terrorists Organisations - FTOs przez Biuro Antyterrorystyczne (Bureau of Counterterrorism) w Departamencie Stanu (Department of State). Natomiast od 2003 roku sporządzana jest przez FBI baza danych z nazwiskami osób podejrzanych o terroryzm (wewnętrzny i międzynarodowy) - ,Terrorism Screening Database”, zwana „Terrorist Watchlist”. Warto zaznaczyć, że pierwszą kobieta, która znalazła się na liście FBI najbardziej poszukiwanych terrorystów na świecie w 2013 roku, jest Joanne Deborah Chesimard, znana także jako Assata Shakur, związana najpierw z Czarnymi Panterami (Black Panthers), a potem z Czarną Armią Wyzwolenia (Black Liberation Army - BLA). BLA wywodząca się od Czarnych Panter była aktywna w latach 70. XX wieku. J. Chesimard podczas udziału w napadzie na bank 2 maja 1973 roku w Nowym Jorku zabiła $z$ broni palnej funkcjonariusza policji stanowej. Zatrzymana i skazana na dożywocie zbiegła z więzienia, dzięki pomocy innych członków BLA, w New Jersey 2 listopada 1979 roku. Przypuszcza się, że ukrywa się na Kubie. Wysokość nagrody oferowana przez FBI za informacje o miejscu pobytu ściganej wynosi $1 \mathrm{mln}$ USD, dodatkowo stan New Jersey zaoferował 1 mln USD (FBI 2013a).

Analizując aktywność poszczególnych ugrupowań można stwierdzić, że największe zagrożenie dla bezpieczeństwa wewnętrznego tworzą takie organizacje, jak: ALF, ELF (ekoterroryzm), Armia Boga/The Army of God - AG, Baranki Chrystusa/Lambs of Christ (terroryzm antyaborcyjny), Creativity Movement, Ku Klux Klan - KKK (supremacjonistyczny/terroryzm religijny), National Alliance, Narody Aryjskie/Aryan of Nations (terroryzm prawicowy). Na terenie USA aktywne były również organizacje skrajne, 
łączące koncepcje rasistowsko-religijne, jak np. syjonistyczne (Liga Obrony Żydów/Jewish Defense League), ruch czarnego rasizmu (Black Panthers, New Black Panthers for Self Defense, Nation of Islam), (Peck, 2010; Peck, 2007). Większość tych organizacji posiada swoje lokalne filie i stowarzyszenia, niekoniecznie korzystające z oficjalnej nazwy organizacji centralnej.

Generalnie, próbując przyporządkować aktywność powiązaną z terroryzmem, wyróżnia się pięć zagrożeń: 1) rasizm, 2) radykalizm islamski, 3) terroryzm ekologiczny, 4) terroryzm antyaborcyjny, 5) cyberterroryzm. Przy czym radykalizm islamski postrzega się jako zagrożenie o wymiarze międzynarodowym. Ze względu na kategorię sprawcy należy wyróżnić samotnego wilka (lone wolf). Według bazy danych Global Terrorism Database, sporządzanej przez National Consortium for the Study of Terrorism and Responses to Terrorism (START) na Uniwersytecie Maryland, na terenie Stanów Zjednoczonych w latach 1970-2013 miało miejsce 141 ataków przygotowanych przez sprawców indywidualnych (Global Terrorism Database, 2013). Jednak liczba ta znacznie się zmniejszy, gdy zastosuje się kryterium absolutnie samodzielnego przygotowania i przeprowadzenia ataków bez kontaktów z ugrupowaniami terrorystycznymi. W głównej mierze „samotnymi wilkami", jak dotychczas, są mężczyźni, np. Timothy McVeigh, Theodore Kaczynski „Unabomber”, Eric Robert Rudolph, Ali Hassan Abu Kamal i Nidal Malik Hasan (Simon, 2013; Phillips, 2013). Jedyną kobietą, która została uwzględniona w tych statystykach, była Rachella Shannon, powiązana z ruchem antyaborcyjnym, która usiłowała dokonać zabójstwa dr Georga Tillera 19 sierpnia 1993 roku, przed jego kliniką w Wichita w stanie Kansas. Tiller przeżył, dwukrotnie postrzelony przez R. Shannon, ale 31 maja 2009 roku został zamordowany przez innego działacza ruchu antyaborcyjnego, również zaliczanego do kategorii samotnego wilka, Scotta Roedera.

Prawdopodobnie kobiety przywiązują większą wagę do interakcji społecznych i rzadziej występują u nich antyspołeczne zachowania, w efekcie w mniejszym stopniu są zdolne do zabijania osób trzecich. Opierając się na raportach przestępstw popelnionych na terenie USA w 2012 roku (Uniform Crime Report i National Crime Victimisation Survey), gdzie tylko w $11 \%$ przypadkach sprawczyniami morderstw były kobiety ( 965 na 8514 odnotowanych zabójstw), Peter J. Phillps wysnuwa tezę, że mężczyźni bardziej skłonni są do popelniania brutalnych przestępstw i łamania prawa. Kobiety zaś mogą wykazywać skłonność do popełnienia przestępstw w grupach lub do udzielania poparcia tym grupom, nie zaś do indywidualnego dokonywania brutalnych zabójstw (Phillips, 2013, s. 4; FBI, 2012; Department of Justice, 2012). Dość znamiennym antyprzykładem tej tezy jest sprawa Colleen R. LaRose, okrzykniętej przez media Dżihad Jane (Jihad Jane), znanej poprzez swoją aktywność w propagowaniu idei dżihadu w sieci Internet jako Fatima La Rosa. Została ona aresztowana w 2009 roku i na początku 2014 roku skazana na 10 lat więzienia za udział w nielegalnym spisku, którego celem było zabójstwo znanego szwedzkiego rysownika Larsa Vilksa. Vilks stał się celem też Al-Qa'idy za opublikowanie karykatury Mahometa przedstawionego z głową $\mathrm{psa}^{3}$. Znamienne jest to, że

\footnotetext{
${ }^{3}$ Pierwszą gazeta, która je opublikowała, była duńska „Jyllands-Posten” w 2006 roku. Lokalna szwedzka gazeta „Nerikes Allehanda” 19 sierpnia 2007 opublikowała rysunek przedstawiający glowę proroka Mahometa na ciele psa, również inne gazety europejskie poszly jej śladem. Wywołało to szereg protestów w krajach muzulmańskich. Abu Omara al-Bagdadi, przedstawiciel terrorystycznej organiza-
} 
LaRose przeprosiła za swoje zachowanie i zadeklarowała, że nie będzie brała więcej udziału w świętej wojnie.

Pojawiają się głosy badaczy, że brak poparcia dla kobiet uczestniczących w walce wynika z obrony dominacji mężczyzn. Wyłączenie zaś kobiet z walki terrorystycznej jest walką ze światem charakteryzującym się nieporządkiem seksualnym. Narracja religijna zaś strzeże „porządku naturalnego”. Bartosz Bolechów zwraca uwagę, że terroryzm religijny kultywuje męskość i „,archetyp mężczyzny-wojownika zgoła herosa przywracającego światu zachwianą równowagę i odzyskującego swój - poprzednio zakwestionowany status w świecie" (Bolechów, 2010, s. 197-198). Pojawia się pytanie, czy jednym z wielu uwarunkowań terroryzmu religijnego jest kryzys męskości i nienawiść do kobiet? Wątpliwe.

Radykalne nurty islamskie stopniowo legitymizują udział kobiet. Jest to związane z takimi kwestiami, jak m.in.: problem nagrody dla męczennika, różnica płci i czystości seksualnej. Rewolucyjne zmiany, jakie pociagałoby uznanie przez całą społeczność muzułmańską partycypacji kobiet, nie są jeszcze widoczne. Niemniej warto zauważyć, że najwięcej kobiet zaangażowanych w dżihad na wielką skalę jest w Palestynie i Czeczenii, czyli w dwóch najbardziej zsekularyzowanych i dobrze wykształconych społecznościach w świecie muzułmańskim, przy czym ich walka ma charakter narodowo-wyzwoleńczy a nie stricte religijny (Cook, 2008, s. 46-47).

Ciekawym przykładem zaangażowania kobiety w terroryzm międzynarodowy było zatrzymanie pod koniec 1999 roku Lucii Garofalo, obywatelki Kanady, podejrzanej o współpracę m.in. z członkami Al-Qa'idy i Algierskiej Grupy Zbrojnej (Groupe Islamique Armé - GIA). Garofalo zajmowała się przede wszystkim logistyką w tym szmuglowaniem ludzi przez granicę kanadyjsko-amerykańską. Została aresztowana wraz ze swoim mężem Bouabide Chamchiem, Algierczykiem z pochodzenia, przy próbie przekroczenia granicy 19 grudnia 1999 roku. Prawdopodobnie pomagała również w przedostaniu się do Stanów Zjednoczonych znanemu algierskiemu terroryście Ahmedowi Ressamowi, który został zatrzymany pięć dni wcześniej. Udowodniono mu planowanie w noc sylwestrową zamachu na lotnisku międzynarodowym w Los Angeles. Zaś Garafalo i jej męża, ze względu na współpracę ze śledczymi i brak przekonujących dowodów, ukarano grzywną za łamanie prawa migracyjnego (Associated Press, 2000; Nance, 2014, s. 242-243).

W latach 1970-2011 na terenie Stanów Zjednoczonych przeprowadzono łącznie 2608 zamachów terrorystycznych, które w ponad połowie były przeprowadzone przy użyciu materiałów wybuchowych, ataków ze skutkiem śmiertelnym było 226. Pod względem terroryzmu wewnętrznego największą liczbę ofiar pochłonął zamach na budynek federalny w Oklahoma City w 1995 roku - 168. Organizacjami, które dokonywały najwięcej zamachów od 2001 do 2011 roku, były: Earth Liberation Front, odpowiedzialny za 50 udanych ataków i Animal Liberation Front również 50. Nie należy zapominać także o problemie terroryzmu międzynarodowego. Zamach z 11 września 2001 roku z łączną liczbą 2996 ofiar śmiertelnych, był jak dotychczas najtragiczniejszym w skutkach ata-

cji Al-Qa'ida w Iraku, wyznaczył 100 tys. dolarów nagrody za zabójstwo Larsa Vilksa. Na 50 tys. dolarów nagrody wyceniono życie Ulfa Johanssona - redaktora naczelnego szwedzkiej gazety „Nerikes Allehanda". 
kiem. W statystykach tych nie zostały uwzględnione akty powiązane z terroryzmem, jak m.in. wandalizm, sabotaż, nękanie i kradzieże charakterystyczne dla ekstremizmu ekologicznego. FBI szacuje, że ekstremiści środowiskowi od 1979 roku do początku 2009 popełnili łącznie między 1800 a 2000 incydentów kryminalnych, szkody kalkulowane są na wartość $110 \mathrm{mln}$ USD (Bjelopera, 2013, s. 40). Inne aktywne organizacje w tym okresie powiązane były z ruchami ekologicznymi to np.: Revolutionary Cells-Animal Liberation Brigade (Komórki Rewolucyjne Brygada Wyzwolenia Zwierząt) oraz Justice Department (Departament Sprawiedliwości) i z działalnością rasistowską, np. Minutemen American Defense, Ku-Klux Klanem (Plumer, 2013).

Ze względu na dość silną radykalizację grup działających na rzecz ochrony natury i obrony praw zwierząt, przyjęto w 1992 roku The Animal Enterprise Protection Act (AEPA 1992), w dalszej kolejności Ecoterrorism Prevention Act w 2004 roku (EPA 2004), a dwa lata później Animal Enterprise Terrorism Act (AETA 2006). Szczególnie AEPA budził kontrowersje, gdyż zrównał przestępstwa zagrażające życiu z uszkodzeniem mienia lub narażeniem na straty materialne. Głośną sprawą był proces 6 aktywistów amerykańskiego oddziału SHAC (Stop Huntingdon Animal Cruelty), których skazano w marcu 2006 roku na 4-6 lat więzienia za m.in. narażenie przedsiębiorstw na straty i udział w demonstracjach ( $\$ 43$ pkt 1-3 AEPA). Jedną z osadzonych na 40 miesięcy w więzieniu Danbury w Connecticut była Lauren Gazzola, która zaangażowana była w kampanię internetową US-SHAC, upubliczniającą m.in. informacje dotyczące badań laboratoryjnych na zwierzętach w New Jersey. Zgodnie z AEPA uznano ją za terrorystkę (Gazzola, 2012).

Zagrożenie terroryzmem wewnętrznym dla decydentów politycznych - oprócz skali incydentów powiązanych przede wszystkim z terroryzmem środowiskowym, niekonwencjonalnej taktyki - jak np. monkeywreanching (Posłuszna, 2012, s. 174-176) i polityczne nękanie (Doan, 2007, s. 27); użycia Internetu, decentralizacji struktur (koncepcja oporu bez przywództwa, dualizm: małe aktywne komórki i reprezentacja polityczna często działająca legalnie) - winno koncentrować się również na problemie radykalizacji postaw w więzieniach (Bjelopera, 2013). Słynną grupą, działającą w zakładach karnych jest Bractwo Aryjskie (Aryan Brotherhood), specjalizujące się w morderstwach na współwięźniach i handlu narkotykami. Znamiennym jest, że kobiety oficjalnie nie mogą być członkiniami Bractwa. Jednak poprzez liczne powiązania osobiste (najczęściej związki emocjonalne) udzielają wsparcia logistycznego i finansowego dla poszczególnych filii, działających głównie na terenie stanów Arizony, Teksasu, Kalifornii i Ohio.

\section{Wściekla biala kobieta}

W ostatnich latach wzrosła drastycznie kampania organizacji prawicowych, prowadzonych przy pomocy Internetu, m.in. Stormfront i Światowego Kościoła Twórcy (World Church of the Creator - WTCOTC) (Bjelopera, 2013). Za najbardziej zasłużona kobietę w „narracji” (proliferacji zakazanych treści i promocji nienawiści rasowej) uważa się Elishę Strom, znaną pod pseudonimem „Wściekła Biała Kobieta” (Angry White Female). Oprócz niej wymienia się Lisę Turner, powiązana z WCOTC, która założyła Women's Frontier w ramach ruchu i Rachel Pendergraft z Ku Klux Klanu. W tych orga- 
nizacjach kobiety pełnią funkcje bardziej legitymizujące i promujące (przestępstwa okołoterrorystyczne i pomocnicze, m.in. rekrutacja, szkolenie, logistyka, propaganda) niż aktywnie angażują się w sam akt terroryzmu (Cunningham, 2012, s. 440; Blee, 2005). Podobne tendencje zaobserwować można w ruchu antyaborcyjnym, ze skrajną Armią Boga na czele, gdzie kobiety angażują się przede wszystkim w akcje protestacyjne (tzw. „akcje ratunkowe"), sabotażowe, kampanie medialne oraz lobbing polityczny. Działalność ta nie jest stricte działalnością terrorystyczną, bardziej przypomina nękanie, natomiast element rozróżnienia pośredniego i bezpośredniego celu oraz psychologicznego oddziaływania mieści się w pewnym sensie w naukowym ujmowaniu terroryzmu (Primoratz, 1997; Sinnott-Armstrong, 1997). Na działania składają się ustawiczne akcje prowadzone przez zorganizowane grupy, które wykorzystują werbalne, często też fizyczne środki wywarcia wpływu na inne osoby, poprzez wywołanie strachu. Najczęściej sprowadzają się one do prześladowania lekarzy (poprzez procesy sądowe, np. za błędy lekarskie) i pracowników klinik oraz do protestów przed wejściami do placówek oferujących zabiegi aborcji (tzw. sidewalk counseling) ${ }^{4}$. W swojej historii ruch pro-life również zasłynął atakami z użyciem materiałów wybuchowych (czę́ciej była to groźba popełnienia takiego przestępstwa), kwasu masłowego czy groźbą zakażenia wąglikiem (rozsyłanie listów z rzekomą bakterią), od 1993 roku dokonano 8 zabójstw (NARAL 2014).

„Anglosas boi się przeludnienia i tłoku. Utrzymuje, że wierzy w istoty ludzkie, a także dobroczynność natury; odżegnuje się od czarniejszych, bardziej mrocznych i pesymistycznych poglądów Europejczyków. Odpoczywa w czystym, uporządkowanym, schludnym, cnotliwym świecie, boi się hałasu, zamieszania, brudu, zgęszczenia ludzi i poplątanych emocji [...] Anglosas nie czuje się dobrze we wszechświecie - musi go opanować. W istocie ten wszechświat go przeraża" (Novak, 1988, s. 159). Cytat ten w pewien poetycki sposób przedstawia dramat społeczny motywujący często zachowanie grup odwołujących się do archetypu WASP (White Anglo-Saxon Protestant), połączonego z koncepcją narodu wybranego (Ameryka jako nowy Izrael). Postawa, która będzie prowadziła do zachowań wykluczających i dyskryminujących wobec osób uznanych za obce religijnie, rasowo, kulturowo. Protestanci stanowili większość w amerykańskim społeczeństwie od momentu, gdy na dzisiejszym terytorium USA zaczęli osiedlać się pierwsi purytanie. W latach 60. XX wieku dwie trzecie Amerykanów deklarowało przynależność do któregoś z kościołów protestanckich, dzisiaj jest to prawie połowa Amerykanów. Mistyczna rola, jaką naród amerykański miał odegrać, przybrała dwie formy w USA: religii obywatelskiej (civil religion) i supremacjonizmu, z domieszką interpretacji chrześcijańskiej (Peck, 2005). Mit wspólnego pochodzenia (archetyp WASP), będący jednym z filarów tożsamości, będzie prowadził też do nacjonalizmu, który obecnie można zaobserwować w działalności m.in. Narodów Aryjskich i organizacji afiliowanych oraz w ugrupowaniach powiązanych ideowo $\mathrm{z}$ Ku Klux Klanem. Ruchy rasistowskie w USA powiązane są $\mathrm{z}$ fundamentalizmem religijnym, odróżnia je to od rasizmu znanego w Europie w latach 30. XX wieku, który miał wymiar świecki, choć często był podparty mitami czasów pogańskich. Niekiedy ugrupowania w USA nazywane są WSE, jest to akronim od słów

\footnotetext{
${ }^{4}$ Instruktażowy podręcznik dla owej działalności zostal sporządzony przez Jospeha M. Sheidlera, Closed: 99 ways to stop abortion w 1985 roku. Jest ogólnodostępny w Internecie.
} 
white supremacis extremism. Termin zaś RAHOWA - odnosi się do Racial Holy War (świętej wojny rasowej) - jest jednym $\mathrm{z}$ podstawowych haseł $\mathrm{m}$.in. powiązanego ze wspomnianym Kościołem Twórcy - neonazistowskiego Creativity Movement (Levin, 2006).

Białe kobiety działały również w organizacjach związanych z Czarnymi Panterami. FBI na listę poszukiwanych wpisała $\mathrm{m}$. in. - za udział w uprowadzeniu samolotu 3 czerwca 1972 lot 701 z Los Angeles do Seatle z 97 pasażerami na pokładzie - Catherine Marie Kerkow. Kerkow udało się uzyskać azyl polityczny w Algerii. Na liście FBI obecnie poszukiwanych terrorystek, powiązanych z ugrupowaniami wewnętrznymi, znajdują się również kobiety związane z nurtem lewicowym, m.in. Josephine Sunshine Overaker, która jest podejrzana o liczne podpalenia i kontakty z ALF i ELF, Elisabeth Anna Duke i Donna Joan Borup, powiązane z aktywną w latach 1978-1985 May $19^{\text {th }}$ Communist Organization (również znaną jako May 19 Coalition M19CO) (FBI, 2013b). Wcześniej do najsławniejszych twarzy nurtów lewicowych zaliczano członkinie Weather Undergroud - Kethy Boudine, Lindę Evans, Susan Rosenberg, Dianę Oughton i Bernardine Dohrn, dowódcę brygady kobiet (Women's Brigate of Weather Underground ${ }^{5}$ ). Do najsłynniejszych akcji tej jednostki należało: podłożenie ładunku wybuchowego w centrum spraw międzynarodowych na Uniwersytecie Harvarda 14 października 1970 roku oraz w Biurze Departamentu Zdrowia, Edukacji i Spraw Społecznych w San Francisco 6 marca 1974 roku (Jacobs, 1997).

Podsumowując, można wyróżnić - wyłączając powiązania z terroryzmem międzynarodowym - dwa główne nurty współczesnego terroryzmu wewnętrznego w Stanach Zjednoczonych, w których aktywnie angażują się kobiety: po pierwsze, prawicowe organizacje powiązane z WCOTC, Narodami Aryjskimi, milicjami obywatelskimi i organizacjami patriotycznymi, po drugie zaś, organizacje jednej sprawy (,specjalnego interesu”), zarówno lewicowe, jak i prawicowe: ALF, ELF i aktywiści antyaborcyjni. Karla J. Cunningham wyróżnia jeszcze trzeci nurt lewicowy powiązany z ruchem narodowowyzwoleńczym Portorykańczyków (Armed Forces of National Liberation - FLAN i Los Macheteros) (Cunningham, 2003, s. 176-179). Niemniej aktywność terrorystyczna i stosowanie przemocy politycznej w formie zamachów bombowych i napadów rabunkowych przez te organizacje przypadała na drugą połowę lat 70. i lata 80. XX wieku. Mimo że Boricua Popular Army, zwana popularnie Los Macheteros, wciąż istnieje, to jej działania znacznie osłabły po śmierci lidera - Filiberto Ojeda Ríosa (23.08.2005 r.). Obecnie jej aktywność jest marginalna w stosunku do działań przeprowadzanych przez ruchy ekologiczne $i$ animalistyczne.

Człowiek nie rodzi się terrorystą, ale w pewnych okolicznościach się nim staje (Zimbardo, 2008), to założenie stanowi podstawę studiów/rozważań nad terroryzmem. Przesłanki sytuacyjne, kulturowe i osobiste są tak liczne i często złożone, że trudno znaleźć jednoznaczną odpowiedź na pytanie o przyczyny zaangażowania się w terroryzm. Formy początkowej fascynacji przemocą polityczną starannie podtrzymywane i podsycane trwałą działalnością nakierowaną na cel mogą popchnąc kobiety do uczestnictwa w zdarzeniach o charakterze terrorystycznym (Horgan, 2008). Dlatego działania antyterrorystyczne

\footnotetext{
${ }^{5}$ Ta kobieca brygada w 1974 roku zmieniła nazwę na „Proud Eagle Tribe”.
} 
koncentrują się również na eliminacji potencjalnych czynników, w tym środowiskowych, sprzyjających intensyfikacji artykulacji potrzeb i interesów politycznych gloryfikujących przemoc. W celu, między innymi „odciagnięcia” najbardziej narażonych grup społecznych na radykalizację postaw i zachowań, powstał program Countering Violent Extremism (CVE) w ramach Departamentu Bezpieczeństwa Wewnętrznego (DHS). Do głównych zadań CVE, oprócz różnego rodzaju inicjatyw społecznych adresowanych przede wszystkim do młodzieży i więźniów, należą inicjatywy na rzecz angażowania kobiet w bezpieczeństwo społeczności lokalnych, w tym rozpoznawania pierwszych oznak radykalizacji. W dużej mierze działania te wynikają z narodowej strategii z 3 sierpnia 2011 roku (National Strategy, 2011) wspierania społeczności lokalnych w walce z radykalnym ekstremizmem. Generalnie takie podejście zakłada, że działania i poglądy jednostki pod wpływem oddziaływania środowiska ulegają auto-radykalizacji. Czynnikami sprzyjającymi mogą być zarówno predyspozycje psychologiczne jednostki, lecz także postawy, właściwie mentalność polityczno-społeczna (McCauley, Moskalenko, 2008).

\section{Wnioski}

Przyglądając się trendom współczesnego terroryzmu, specyfikacji działań, innowacyjności pod względem taktyki, werbunku i propagandy można wyróżnić dziewięć czynników, nawzajem się dopełniających i nie stanowiących katalogu zamkniętego, decydujących o obliczach współczesnego terroryzmu kobiecego:

- wzrost zaangażowania kobiet (nie tylko w USA) w terroryzm, oraz podlega zdywersyfikowaniu pod względem ról odgrywanych w organizacji;

- niemoc instytucji bezpieczeństwa w radzeniu sobie z tym procesem i zwiększająca się rolą kobiet $w$ organizacjach terrorystycznych aktywnych na terenie USA i powiązanych $\mathrm{z}$ terroryzmem międzynarodowym;

- brak wypracowanych strategii i analiz środowiska kobiecego; zakłada się, że kobiety nie działają w pojedynkę (taktyka „samotnego wilka”);

- przekonanie, że organizacje paramilitarne, w tym terrorystyczne są środowiskiem wrogim dla kobiet;

— postrzeganie kobiet jako zakładnika organizacji/sytuacji (wymuszenie, uprowadzenie), a nie racjonalnego aktora;

- wpływ stereotypów związanych z płcią na medialny portret kobiet, niezależnie czy są one zaangażowane w legalną walkę polityczną, czy uciekają się do radykalnej przemocy politycznej;

- mniejsza podejrzliwość wobec kobiet - terrorystek niż do mężczyzn; dlatego coraz więcej organizacji terrorystycznych będzie wykorzystywać taktyczne zalety kobiet w swoich atakach (Nacos, 2007);

- uznanie ataków terrorystycznych kobiet, szczególnie samobójczych, za bardziej medialne dla sprawy;

- postępująca mobilizacja kobiet przez Internet i media (strony internetowe, fora, czaty, kanały telewizyjne).

Wnioski te można odnieść nie tylko do wewnętrznego terroryzmu w Stanach Zjednoczonych, ale i do innych krajów oraz do obecności kobiet w organizacjach mających 
stricte charakter międzynarodowy. Mit o pasywności kobiet, o tym, że nie stanowią zagrożenia, przede wszystkim politycznego, należy obalić. Próby objaśniania zaangażowania kobiet w działalność terrorystyczną są jeszcze w fazie rozwoju. Głównym wyzwaniem dla badacza są utrzymujące się stereotypy i portrety kobiet-terrorystek (maskulinizacja, cierpienie - „czarne wdowy”) prezentowane w mediach. Tworzą one nieprawdziwe wyobrażenie o irracjonalności wyboru kobiety. Każdy przypadek powinien być rozpatrywany indywidualnie. Rozpatrywany, to znaczy analizowany poprzez rozpoznanie problemu, gromadzenie danych (dotyczących kontaktów osobowych, członków rodziny, wykształcenia, nawyków, religii, życia prywatnego, przebytych chorób itp.), ich przetwarzanie, sformułowanie interpretacji w formie raportu końcowego i klasyfikowanie pod kątem analogicznych wydarzeń, aby wyodrębnić cechy wspólne, a tym samym powtarzalne. Jednego profilu terrorystki, jak i terrorysty nie ma, natomiast kryminologia dostarcza odpowiednie narzędzia do stworzenia profilu sprawcy przestępstwa.

\section{Bibliografia}

AEPA Animal Enterprise Protection Act, Pub. L. 102-343 Aug, 26, 1992.

AETA Animal Enterprise Terrorism Act, Pub. L. 109-374 Nov. 27, 2006.

Associated Press (2000), Woman with alleged terrorist ties gets plea deal, „Los Angeles Times” $\mathrm{z}$ dn. 6 lutego $2000 \mathrm{r}$.

Bazylow L. (1960), Dzialalność narodnictwa rosyjskiego w latach 1878-1881, Zakład Narodowy im. Ossolińskich, Wroclaw.

Berko A. (2010), Droga do raju: świat wewnętrzny zamachowców samobójców, Wydawnictwo Replika, Zakrzewo.

Bjelopera J. P. (2013), The domestic terrorist threat: background and issues for Congress, „CRS Reports for Congress", January 17, 2013, http:/www.fas.org/sgp/crs/terror/R42536.pdf, 18.11.2013.

Blee K. M. (2005), Women and organized racial terrorism in the USA, „Studies in Conflicts and Terrorism", Vol. 28 , $\mathrm{nr} 25$, s. $428-430$.

Bloom M. (2011), Bombshell: women and terrorism, University of Pennsylvania Press, Philadelphia.

Bloom M. (2005), Terror's stealth weapon: women, „The LA Times” z dn. 29 listopada 2005 r.

Bolechów B. (2010), Terroryzm: aktorzy, statyści, widownie, PWN, Warszawa.

Brym R., Araj B. (2012), Are suicide bomber suicidal?, „Studies in Conflicts and Terrorism”, nr 35, s. $432-443$.

Cook D., Women lighting in jihad, w: Female terrorism and militancy. Agency, utility and organization, red. C. D. Ness, Routledge, New York-London, s. 37-48.

Cunningham K. J. (2003), Cross-regional trends in female terrorism, „Studies in Conflict and Terrorism", Vol. 26, nr 3, s. 171-195.

Cunningham K. J. (2012), Countering female terrorism, w: J. Horgan, K. Braddock, Terrorism studies: a reader, Routledge, London-New York, s. 439-453.

Department of Justice (2012), National Crime Victimization Survey 2012, October 2013, http://www.bjs.gov/content/pub/pdf/cv12.pdf, 2.12.2013.

Doan A. E. (2007), Opposition and intimidation: the abortion wars and strategies of political harassment, The University of Michigan Press, Ann Arbor.

El Saaraj E. (2002), Suicide bombers: dignity, despair; and the need of hope, „Journal of Palestine Studies", nr 4, s. 71-76. 
EPA Ecoterrorism Prevention Act, HR $4454 \mathrm{IH}, 108^{\text {th }}$ Congress, May 20, 2004, https://www.govtrack.us/congress/bills/108/hr4454/text, 1.12.2013.

Erez E. (2008), Martyrs or murders? Victims or victimizers?, w: C. D. Ness, Female terrorism and militancy. Agency, utility and organization, Routledge, New York-London, s. 146-166.

Eubank W. L., Weinberg L. (1994), Does democracy encourage terrorism, „Terrorism and Political Violence", Vol. 6, nr 4, s. 417-435.

FBI (2012), Unform Crime Reports 2012, http://www.fbi.gov/about-us/cjis/ucr/ucr, 2.12.2013.

FBI (2013a), The most wanted terrorists, May 5, 2013, http://www.fbi.gov/news/stories/2013/may/ joanne-chesimard-first-woman-named-most-wanted-terrorists-list, 10.11.2013.

FBI (2013b), Wanted by the FBI: domestic terrorism, http:/www.fbi.gov/wanted/dt, 1.12.2013.

FBI (2014), What we investigate, http://www.fbi.gov/albuquerque/about-us/what-we-investigate. 1.01 .2014

Gazzola L. (2012), Animal-Rights Activists Like Me Aren't Terrorists, January 9, 2012, http://otherwords.org/animal-rights_activists_like_me_arent_terrorists/, 2.12.2013.

Global Terrorism Database (2013), http://www.start.umd.edu/gtd/ (2.01.2014).

Horgan J. (2008), Psychologia terroryzmu, PWN, Warszawa.

Irving S. (2012), Leila Khaled: icon of Palestinian Liberation, Pluto Press, New York-London.

Jacobs R. (1997), The way the wind blew: a history of the Weather Underground, Verso, London-New York.

Jacques K., Taylor P. J. (2013), Myths and realities of female-perpetrated terrorism, „Law and Human Behavior", Vol. 37, s. 35-44.

Khaled L. (1973), My People shall live: the autobiography of a revolutionary, Hodder and Stoughton, London.

Levin J. (2006), Domestic terrorism, Chelsea House Pub., New York.

McCauley C., Moskalenko S. (2008), Mechanisms of political radicalization: pathways toward terrorism, „Terrorism and Political Science”, Vol. 20, Issue 3, s. 415-433.

MacDonald E. (1992), Shoot the women first, Random House, London.

Nacos B. L. (2008), The portrayal of female terrorists in the media, w: Female terrorism and militancy. Agency, utility and organization, red. C. D.Ness, Routledge, New York-London, s. $217-233$.

Nance M. W. (2014), Terrorist recognition handbook: a manual for predicting and identtfying terrorist activities, wyd. 3, Taylor \& Francis, Boca Raton.

National Strategy on Empowering Local Partners to Prevent Violent Extremism, Aug. 3, 2011. http://www.whitehouse.gov/sites/default/files/empowering_local_partners.pdf, 1.02.2013.

NARAL Pro-choice America Foundation, Anti-choice violence and intimidation, http://www.prochoiceamerica.org/assets/files/abortion-access-to-abortion-violence.pdf, 2.01.2014.

Ness C. D. (2008), In the name of the cause. Women's work in secular and religious terrorism, Female terrorism and militancy. Agency, utility and organization, red. eadem, Routledge, New York-London, s. 11-36.

Nordstrom C. (2008), (Gender) war, w: Female terrorism and militancy. Agency, utility and organization, red. C. D. Ness, Routledge, New York-London, s. 69-83.

Novak M. (1988), Przebudzenie etnicznej Ameryki, Państwowy Instytut Wydawniczy, Warszawa.

O'Gorman E., Jabri V. (1999), Locating differences in feminist international relations, w: Women, culture, international relations, red. E. O'Gorman, V. Jabri, Lynne Rienner Publishers, London, s. $1-16$.

Peck A. (2005), Teleewangelizm, apokalipsa i polityka: wspótczesna prawica protestancka w Stanach Zjednoczonych, Wyższa Szkoła Społeczno-Gospodarcza, Tyczyn. 
Peck A. (2007), W poszukiwaniu tożsamości: rasizm w amerykańskich koncepcjach religijnych. Zakład Wydawniczy Nomos, Kraków.

Peck A. (2010) Trzecia Światynia jerozolimska w koncepcjach chrześcijańskiego syjonizmu w Stanach Zjednoczonych, Zakład Wydawniczy Nomos, Kraków.

Peterka-Benton D., Benton B. (2014), Effects of cultural collectivism on terrorism favorability, ,Journal of Applied Security Research", Vol. 9, Issue 1, s. 17-40.

Phillips P. J. (2013), Female lone wolf terrorism: the economic analysis of uniquely gendered lived experiences, October 31, 2013, https://papers.ssrn.com/sol3/papers.cfm?abstract_id=2347881, 1.12.2013

Plumer B. (2013), Nine facts about terrorism in the United States since 9/11, „Washington Post” (on-line) z dn. 11 września 2013 r.

Poshuszna E. (2012), Ekstremizm ekologiczny: źródla - przejawy - perspektywy, Wydawnictwo Naukowe Scholar, Warszawa.

Primoratz I. (1997), Czym jest terroryzm?, w: Filozofia moralności. Postanowienie i odpowiedzialność moralna, wyb. J. Hołówka, Spacja, Warszawa, s. 245-259.

Rapoport D. C. (2004), The Four Waves of modern terrorism, w: Attacking terrorism: Elements of a grand strategy, red. A. K. Cronin, J. Ludes, Georgtown University Press, Washington DC, s. $48-73$.

Schmidt A. (1992), Terrorism and democracy, „Terrorism and Political Violence”, Vol. 4, nr 4, s. $14-25$.

Simon J. D. (2013), Lone Wolf Terrorism: understanding the growing threat, Prometheus Books, New York.

Sinnott-Armstrong W. (1997), O Primoratza definicji terroryzmu, w: Filozofia moralności. Postanowienie i odpowiedzialność moralna, wyb. J. Hołówka, Spacja, Warszawa, s. 261-269.

Smith H. L., Carroll B. A. (2000), Women's political \& social thought; an anthology, Indiana University Press, Bloomington.

United States Code (2013), http://uscode.house.gov/, 1.12.2013.

USA PATRIOT Act, Uniting and Strengthening America by Providing Appropriate Tools Required to Intercept and Obstruct Terrorism Acts of 2001, Pub. L 107-56, 26 październik 2001.

Wesley J. K. (2006), Considering the context of women's violence: gender lived experiences and cumulative victimization, „Feminist Criminology”, Vol. 1, nr 4, październik, s. 303-328.

Victor B. (2003), Army of Roses: Inside the world of Palestinian women suicide bombers, PA Rodale Emmaus.

Ziębą A. (2013), Europa nigdy nie będzie bezpieczna, 23 września 2013 r., http://wiadomosci.dziennik.pl/swiat/artykuly/438659, europa-nigdy-me-bedzie-bezpieczna-po-ataku-terrorystow-w-nairobi.html, 23.09.2013

Zimbardo P. G. (2008), Efekt Lucyfera: dlaczego dobrzy ludzie czynia zlo, PWN, Warszawa.

\section{The faces of modern female terrorism on the example of internal terrorism in the United States}

\section{Summary}

The paper presents the issue of female terrorism, focusing primarily on selected examples in the United States. It additionally discusses the issues related to the attempt to answer the question of whether a system of counter-terrorism should take into account the gender of members of terrorist organizations, 
and whether the increasing threat of female terrorism may be one of the catalysts behind institutional and legal changes. Furthermore, the development of female terrorism in other regions of the world is analyzed.

Key words: terrorism, female terrorism, counter-terrorism, USA, WASP, jihad 